\title{
Technically avoidable heavy metal contents in cosmetic products
}

(C) Bundesamt für Verbraucherschutz und Lebensmittelsicherheit (BVL) 2016. This article is published with open access at Springerlink.com

\section{Introduction}

Cosmetic products must not contain any of the substances listed in Annex II to Regulation (EC) No 1223/2009 of cosmetic products (European Commission 2009). These include heavy metals such as lead, cadmium, arsenic, antimony and its compounds as well as mercury and its compounds, except those special cases included as preservatives in Annex V. In accordance with Article 17 of this Regulation, the unintended presence of these heavy metals in cosmetic products is only allowed if it is technically unavoidable under good manufacturing practice (GMP) and if the products are still safe for the human health. The safety has to be demonstrated for each individual case in the safety report of the respective cosmetic product.

These bans do not only exist since the above mentioned Regulation entered into force. In the years 1985 and 1990, the Cosmetic Commission of the

The German version of this article is provided in the supplementary material.

Electronic supplementary material The online version of this article (doi:10.1007/s00003-016-1044-2) contains supplementary material, which is available to authorized users.
German Federal Health Office (BGA) published values for technically avoidable levels (BGA 1985, 1990). These orientation values were considered outdated by the preliminary Commission for Cosmetics in 2005, since it was expected that the levels of heavy metals have declined in cosmetic products; therefore, lower technically unavoidable levels are achievable by applying good manufacturing practice.

Potential heavy metal contaminations can be expected particularly in cosmetic products containing high levels of inorganic or mineral components, especially powder and cream products, decorative cosmetics and toothpastes.

The German Monitoring Scheme is a system of repeated representative measurements and evaluations of levels of substances which are undesirable from a health point of view. From 2010 to 2012, the Monitoring Scheme created a data basis to derive current representative orientation values with an adequate sample size within all relevant product categories. A total of 1735 samples from the product groups baby powder, lipstick, lip rouge, lip powder, lip liner, mascara, eyelid line, eye liner, kajal, eye shadow, tinted cream, camouflage, rouge as well as theater, fan or carnival make-up, children's toothpaste and toothpaste were analyzed for the elements lead, cadmium, mercury, arsenic and antimony. The determination of the elements was conducted with a standardized convention method, bringing the elements under defined conditions into solution (BVL 2011a). According to the market offer, half of the products came from the domestic market or from other EU Member States. Representative sampling was performed. Details on the examination numbers 
Table 1 In future, heavy metal contents in cosmetic products exceeding the following values are considered as technically avoidable

\begin{tabular}{lll}
\hline Element & $\begin{array}{l}\text { Cosmetic products } \\
\text { in general }(\mathrm{mg} / \mathrm{kg})\end{array}$ & $\begin{array}{l}\text { Toothpaste } \\
(\mathrm{mg} / \mathrm{kg})\end{array}$ \\
\hline Lead $(\mathrm{Pb})$ & $2.0^{\mathrm{a}}$ & 0.5 \\
Cadmium (Cd) & 0.1 & 0.1 \\
Mercury (Hg) & 0.1 & 0.1 \\
Arsenic (As) & $0.5^{\mathrm{b}}$ & 0.5 \\
Antimony (Sb) & 0.5 & 0.5
\end{tabular}

${ }^{a}$ For the products make-up powder, rouge, eye shadow, eye liner, kajal, as well as theater, fan or carnival make-up: $5 \mathrm{mg} / \mathrm{kg}$

${ }^{b}$ For theater, fan or carnival make-up: $2.5 \mathrm{mg} / \mathrm{kg}$

and results are described in the monitoring reports ${ }^{1}$ from 2010 to 2012 (BVL 2011b, 2012, 2013).

The results show that an exceedance of the BGA standard values are usually not getting exhausted, although it cannot be excluded for individual samples. For a multitude of samples, the levels were below the limit of determination or detection, which required a recalculation of statistical ratios by the lower bound method, in addition to the published reports. Therefore, the following reductions are possible (Table 1):

\section{Lead}

Concerning lead, there are critical product groups with relatively high levels, such as make-up powder, blush, eye shadow, kajal including eyelid line and eyeliner as well as theater, fan and carnival makeup. For all other products, the 90th percentile is below $2 \mathrm{mg} / \mathrm{kg}$, so that levels above $2 \mathrm{mg} / \mathrm{kg}$ are technically avoidable. For toothpaste, amounts above $0.5 \mathrm{mg} / \mathrm{kg}$ are technically avoidable.

\section{Cadmium and mercury}

For cadmium and mercury, the 90th percentile is significantly below $0.1 \mathrm{mg} / \mathrm{kg}$; therefore, levels above $0.1 \mathrm{mg} / \mathrm{kg}$ are technically avoidable for all products including toothpaste.

\section{Arsenic}

The critical product group with relatively high arsenic levels is theater, fan and carnival make-up. For all other product groups, the 90th percentile is

\footnotetext{
${ }^{1}$ http://www.bvl.bund.de/EN/08_PresseInfothek_engl/04_ reports/presseInfothek_reports_node.html.
}

between 0.5 and $0.9 \mathrm{mg} / \mathrm{kg}$, even taking into account the specific reception conditions of toothpastes, levels above $0.5 \mathrm{mg} / \mathrm{kg}$ can be considered technical avoidable with good manufacturing practice.

\section{Antimony}

For antimony, the 90th percentile in all product groups is below $0.5 \mathrm{mg} / \mathrm{kg}$. Thus, levels above $0.5 \mathrm{mg} / \mathrm{kg}$ are technically avoidable. In special products containing plastic particles, especially polyethylene terephthalate (PET) used e.g. for glitter effects, a higher amount of antimony could be present as result of the production process.

In addition, results regarding lead content in lipsticks from the Joint Research Centre of the European Commission (JRC) show that $90 \%$ of the samples contained $\leq 2 \mathrm{mg} / \mathrm{kg}$ of lead (JRC 2011).

These concerns are about prohibited substances and efforts to achieve further reduction through responsible raw material choices and good manufacturing practice should be maintained.

Bundesamt für Verbraucherschutz und Lebensmittelsicherheit, Mauerstraße 39-42 10117 Berlin

105@bvl.bund.de

Open Access This article is distributed under the terms of the Creative Commons Attribution 4.0 International License (http://creativecommons.org/licenses/by/4.0/), which permits use, duplication, adaptation, distribution and reproduction in any medium or format, as long as you give appropriate credit to the original author(s) and the source, provide a link to the Creative Commons license and indicate if changes were made.

\section{References}

BGA (1985) Mitteilungen des Bundesgesundheitsamtes: Technisch vermeidbare Gehalte an Schwermetallen in kosmetischen Erzeugnissen. Bundesgesundheitsblatt 28(7):216

BGA (1990) Mitteilungen des Bundesgesundheitsamtes: Technisch vermeidbare Gehalte an Schwermetallen in Zahnpasten. Bundesgesundheitsblatt 33(4):177

BVL (Hrsg.) (2011a) Amtliche Sammlung nach § 64 des LFGB, Methode K 84.00-29 2011-03: Druckaufschluss zur Bestimmung von Elementen in kosmetischen Mitteln

BVL (2011b) Berichte zur Lebensmittelsicherheit 2010-Monitoring. Gemeinsamer Bericht des Bundes und der Länder. http:// www.bvl.bund.de/SharedDocs/Downloads/01_Lebensmittel/ 01_lm_mon_dokumente/01_Monitoring_Berichte/archiv/ lmm_bericht_2010.pdf?_blob=publicationFile\&v=9. Accessed 13 Aug 2016

BVL (2012) Berichte zur Lebensmittelsicherheit 2011-monitoring-Gemeinsamer Bericht des Bundes und der Länder, Internetseite des BVL http://www.bvl.bund.de unter 
Lebensmittel, Aufgaben im Bereich Lebensmittel, Monitoring, Archiv der Berichte zum Monitoring. Accessed 17 Aug 2016

BVL (2013) Berichte zur Lebensmittelsicherheit 2012-monitoring-Gemeinsamer Bericht des Bundes und der Länder, Internetseite des BVL http://www.bvl.bund.de unter Lebensmittel, Aufgaben im Bereich Lebensmittel, Monitoring, Berichte. Accessed 17 Aug 2016

European Commission (2009) Verordnung (EG) Nr. 1223/2009 des Europäischen Parlaments und des Rates vom 30.
November 2009 über kosmetische Mittel. Amtsblatt der Europäischen Union. http://www.msdseurope.de/data/ files/197871618.pdf. Accessed 17 Aug 2016

JRC (2011) Results of European Survey on Lead in Lipsticks. In: Piccinini P, Piecha M, S. Fortaner Torrent (eds) EUR 24886 EN-2011. http://www.reach24h.com/cn/download/JRC_Pb_ lip_products_survey.pdf. Accessed 17 Aug 2016 